\title{
Cone's binary view of Africanness and Christianity through the eyes of his African American critics
}

\section{Jakub Urbaniak ${ }^{1}$}

\section{ABSTRACT}

Unlike some of his American colleagues, James Cone tended to distance Black Theology from Africanness in general and African Traditional Religions in particular. Throughout his life this tendency has evolved, but never disappeared altogether. This article sets out to achieve three goals. First, I give a historical account of Cone's relationship with Africa, particularly with African religiosity, focusing on the criticism he received from his colleagues in the U.S. (notably Gayraud Wilmore, Cecil Cone and Charles Long). Second, I analyse the tension between the Christian and the African in Cone's theological outlook by probing his notion of indigenization/Africanization among others. Third, I seek to interpret Cone's binary view of Christianity and Africanness in the light of his chief locus of enunciation, namely Western Christianity (albeit contested). My attempt here is to lay foundations for an engagement with Cone's attitude toward Africanness from the current South African (decolonial) perspective by considering it, first, within its original African American context.

Keywords: James Cone, Africanness, Gayraud Wilmore, Cecil Cone, Charles Long

\section{Introduction}

A number of authors have commented on James Cone's links with Africa, and especially on his legacy in South African Black Theology [BT]. The negative aspect of this relationship has generally received less attention than the positive one. Unlike some of his American colleagues, Cone had a tendency to distance BT from Africanness in general and African Traditional Religions [ATR] in particular. Throughout his life, as his engagements with African theologians started shaping his theological outlook, this tendency has evolved, but never disappeared altogether. If for no other reason, this issue deserves more attention from theologians in a context like ours, since throughout our continent African Christianity is increasingly considered as a religion in its own right and a religion within which African Initiated Churches occupy a central position (Maluleke 2005:123).

Jakub Urbaniak is of Polish origin and came to South Africa in 2010 from France where he completed his doctoral studies. He is a research fellow at the Faculty of Theology and Religion, University of the Free State, and an Associate Professor in Theology, Philosophy of Religion and Ethics at St Augustine College, a Catholic University in Johannesburg. His current research focuses on the intersection of decolonization and Christianity, particularly in the context of South African \#MustFall movement and African religiosity. 
This article sets out to achieve three goals. First, I give a historical account of Cone's relationship with Africa, and especially with African religiosity, focusing on the criticism he received from his colleagues in the United StatesU.S. (notably Gayraud Wilmore, Cecil Cone and Charles Long). Second, I analyse the tension between the Christian and the African in Cone's theological outlook by probing his notion of indigenization/Africanization among others. Third, I seek to interpret Cone's binary view of Christianity and Africanness in the light of his chief locus of enunciation, namely; Western Christianity (albeit contested).

On a broader note, Cone's ambivalent attitude towards Africanness raises questions about the relevance of his Western critique of the West to the decolonial project as it currently unfolds in South Africa among other places. I elaborate on such questions somewhere else (Urbaniak 2018b). Here my attempt is to lay foundations for an engagement with Cone's attitude toward Africanness from the current South African (decolonial) perspective by considering it, first, within the African American context from which it had emerged.

\section{Cone's "alien methodology" according to his African American critics}

In his analysis of the development of BT, a student of Cone, Dwight Hopkins (1999:12) distinguishes four fundamental building blocks, namely; slave religion, a rereading of the Bible, the 1960s black theology movement, and a new method of doing theology. These four blocks amount, in his view, to the theological foundations laid by the first generation of black theologians in the U.S., especially Cone himself. Tellingly, "conversations with and insights from the decolonization experiences of black people and movements in the southern hemisphere" (Kalu 2006:584) are mentioned as a factor in shaping BT in North America only later in the book where Hopkins' discussion focuses on the challenges to the second generation of black theologians who faced "a threatening possibility of selling out the interests of the gospel message and the best interests of the black church" (1999:12).

This reflects well Cone's own binary view of Christianity and Africanness. His initial reluctance to include African perspectives in his theological reflection is not surprising if one bears in mind that his Western upbringing and education (including his graduate studies in theology and history) simply did not expose him, either existentially or intellectually, to things African (Cone 1986:94). He did not see (yet) the theological imperative connecting decolonial struggles of African people with the anti-racist movements in his own country. ${ }^{2}$ Already suspicious of a certain no-

2 In his book My Soul Looks Back, Cone recalls: “...even before my dialogue with Africans, I was severely criticized by several black theologians for failing to include Africa in my theological perspective. The dialogue with Africans, the criticism of black theologians, and the black nationalist proclamation that 
tion of "black religion," the early Cone was even less inclined to understand and appreciate the role of ATR in black people's resistance against colonial powers.

Later in his life, Cone's exclusive focus on racial injustice in the U.S. had been expanded to incorporate liberation struggles of African Christians. As he explains himself, this happened largely because of his "involvement in the National Conference of Black Churchmen (NCBC) and the Society for the Study of Black Religion (SSBR), both of which initiated dialogues with African theologians" (1986:96). However, his suspicion towards black religion (particularly insofar as it understood itself as inclusive of ATR) remained a distinguishing mark of his attempts to navigate the twofold identity of BT: Christian and African. Indeed, Cone has always thought of these two facets in black Christians' experience dialectically.

This thesis can be unpacked on two levels. The first level concerns Cone's difficulty with Africanness as such, which - I believe - is rooted ultimately in his ambivalent sense of his own identity. Based on his writings, it is clear that the category of blackness sat much more comfortably with him than that of Africanness. Even if it is true that in the depths of his being Cone felt "more African than European" (1986:97), it would not be unjustifiable to claim that, in his intellectual expression, he was more black than African (Urbaniak 2018b). His black identity, "so inextricably tied to North America" (Cone 1979:177), was the source of Cone's deep existential conflict inherent in his "double identity as American and African" (1979:177). While describing the nature of this conflict, Cone recalls Du Bois' classic remarks about the "double consciousness" and "twoness - an American, a Negro; two souls, two thoughts, two unreconciled strivings; two wanting ideals in one body, whose dogged strength alone keeps it from being torn asunder" (Du Bois 2018:3; cf. Cone 1979:177). The second level has to do with Cone's commitment to the universal claim of Christian faith (1979:178) and his related belief that "the universal dimension of the Gospel [Christianity]... transcends culture [Africanness, among others]" (1979:180).

For Cone, BT was essentially a Christian theology and thus it developed a distinctly Christian identity within a broader framework of black religion. He was defensive of that Christian identity insofar as he saw it threatened by "confusion and misdirection" brought about by some black scholars in North America whose pluralistic and broad definition of black religion has often led to loosening "their identity with the faith of the black church" (Cone, 1986:98).

Wilmore's "black religious thought," with its heavy leaning on non-Christian sources, is probably the most classical (though not the most radical) example of

'we are an African people', led me to ask how Africa's struggle for political independence was connected with black people's struggle for freedom in North America" (1986:96). 
this tendency. Wilmore's reconstruction of the parameters of BT's sources aims at creating "a black theology of liberation representing all (mainly the unrecognized non-Christian) faith traditions in the black community and to remain accountable to God's liberation movement in both black Christian and non-Christian projects" (Hopkins 2005:84). Wilmore claims that, within the black communities around the world, "God has spoken in diverse ways" (Interview of 19th February 1987 cited in Hopkins 2005:84), thus granting a general revelation status to non-Christian liberation sources such as the novels of Richard Wright and poems of Claude McKay as well as the unbinding of the Spirit in ATR ${ }^{3}$ among others (Hopkins, 2005:84). Insofar as these diverse loci serve as means of the divine liberation of black people, Wilmore considers them as valid as Scripture and church dogmas. Indeed, he deems "the revalorization of the image of Africa" (1999: ix) one of the three basic characteristics of the radical tradition in black religion. Oscillating between an inclusivist and a pluralist position, he believes that:

Despite significant differences, the essential truths of African Traditional Religions, Judaism, Christianity, and Islam have reinforced one another in diverse times and places across the broad stretch of sub-Saharan Africa. us, we acknowledge Th the mystery of the universal revelation of God. Some knowledge of the true God... was given to the African people long before the "arrival" of Judaism from Palestine, the three "visits" of Christianity from Palestine and Europe, and the conquest of Islam from Arabia (2004:118).

In brief, for Wilmore it was the complete uniqueness of black religion that constituted the proper subject matter of Black Theology, not Christian categories as defined by white theology (Wilmore \& Cone 1979:617).

Hopkins questions among other things the lack of refinement in Wilmore's Christology, which in Hopkins' view is responsible for "a seeming unclarity on how a black Christian theology of liberation, committed to the black church, should relate to non-church and non-Christian theological sources" (Hopkins 2005:85). This is in tune with Cone's own objections against the pluralistic accounts of black religion. As a black Christian theologian, Cone was troubled by "the seemingly easy way in which black North American theologians' identity with Africa" made them

3 Wilmore defines ATR as "the primal, basically monotheistic if operationally polytheistic and heterogeneous religions of Africa that stretch backward into the dim reaches of prehistory and forward, in many localized forms and languages, into modern Africa. It is the worship of God and gods, closely identified with primordial ancestors, tribal histories, and founders of ethnic groups and civilizations that exists in all parts of the continent" (2004:100). 
susceptible to compromising their Christian faith, "as if African Traditional Religions could replace Christianity for blacks in North America" (1986:98).

For Cone, Christ was the final norm for BT (1986:97ff): "There can be no Christian theology which does not have Jesus Christ as its point of departure" (Cone 1970:5). BT had to be grounded in the Bible, in the good news about the liberating God, which in Cone's eyes was consistent with the preferential option for oppressed suffering blacks. Without this grounding, it would have no potency to convert people's lives and to reveal the truly universal foundation for Christian common historical commitment. If "there is only one history, one Creator, and one Lord and Saviour Jesus Christ" then - Cone logically concludes - we must "recognize the limitations of our particularity so that we will not ignore the universal claims that the Gospel lays upon all of us" (1979:180). Cone's theology was never separated from his faith, just like his commitment to God was never separated from his commitment to the oppressed, and to the black church in particular (Wilmore \& Cone 1979:138). ${ }^{4}$

The emphasis on the pluralistic nature of black religion, as reiterated by some of his fellow black scholars, appeared to him, it seems, as an abstract academic claim which was not reflected in their Christian ministry. He saw their attitude as dishonest, even hypocritical. Whether this was the case or not, Cone felt that he was under attack because of his commitment to the gospel as the ultimate reference for BT.

I began to notice that many black scholars said one thing in an academic setting but another on Sunday morning in a black church... I did not share the view that black religion was more African than Christian. Because of my persistence in grounding black theology in the Bible and the black struggle for freedom, and not African traditional religions, I was often sharply criticized by my colleagues (Cone 1986:98).

James Cone's brother, Cecil Cone, offered what perhaps remains the most pointed criticism of BT á la James Cone, rightly identifying Christology as its innermost core and accusing it of being "inconsistent with the full range of the black religious experience" (Clark 2012:12). Cecil argued that "Cone's Christ is being pulled apart" due to Cone's failure to recognize "the irreconcilability of Black Power and established academic theology [in the U.S.]" (Cone [Cecil] 1974:81). Ultimately, what Cecil considered the fundamental flaw in his brother's theological approach was Cone's commitment to "an alien theological methodology" (1974:77). In the same vein, Wilmore and others

4 Like for Schleiermacher, for Cone "theology pertains to the church" (Cone, 1970:1; cf. also Schleiermacher 1928). Hence his reservations towards "a black religious nationalism that seemed unconnected with the life experiences of black church people” (Cone, 1986:97). 
deemed Cone's Christology "too heavily dependent on European theology, particularly as represented in the Christology of Karl Barth" (Clark 2012:13).

The grounds for such criticism may not be easily discernible if Cone's theological evolution is taken into account. After all, Cone himself came to criticise Western (white) theology, including the Barthian neo-orthodoxy, for having "consistently misconstrued who Jesus was and what he came to do" (Cortez 2016:191). In the Preface to the 1989 edition of Black Theology and Black Power, he recalls:

I had been greatly miseducated in theology and it showed in the neo-orthodox, Barthian perspective of [the original edition of] Black Theology and Black Power. (...) As I began to reflect more deeply upon my own cultural history, tracing it back to the African continent, I began to see the great limitations of Karl Barth's influence upon my Christological perspective. Barth's assertion of the Word of God in opposition to natural theology in the context of Germany during the 1930s may have been useful. But the same theological methodology cannot be applied to the cultural history of African-Americans (Cone 1997:kxi-xii).

As a result, in his more mature work, Cone turned Barth's theology "inside out" as he struggled to find resonance between Barth's approach of theology and the ghetto, the lived experiences of the black church (Vellem, 2018). In his later deWesternised approach, following the liberation theology's standard modus operandi, Cone builds his Christology around the hermeneutical circle in which situation and gospel are related dialectically (Küster, 2001:149). This is why he believes that God's self-revelation in Christ is "only properly understood when viewed in light of the existential situation of an oppressed community" (Cortez, 2016:192). More specifically, he considers the Black Power movement as the central message to 20th century America, a message which is consistent with the gospel on the question of discovery of identity (Küster, 2001:149).

Referring to Paul, Cone speaks of "the new black man... whose new-found identity is grounded in Christ" ["the new creature in Christ"]. It is the overcoming of the sin of denial by internalizing the alien perspectives which produce discrimination, and the status of "sin's against-ness," whether as a black person or a poor person. The function of Christology in creating identity is the impulse for a tremendous anthropological optimism (Küster 2001:143-144).

And yet even Cone's notion of "the Black Messiah"s remains in many ways grounded in the mainstream Western theology insofar as Cone heavily relies on "non-black,

5 Talking about Christ as "the Black Messiah," Cone uses blackness as an abstract term which has 
European theologies to deal with the problem of black suffering, and as normative in relation to the black experience" (Forrest, 1987:35). For instance, like in Barth, "Jesus becomes 'the decisive Other' who is present in the world today as the one who will eventually establish the kingdom, bring about justice, and end oppression. Jesus' presence includes his promise" (Cortez, 2016). Even in his later book My Soul Looks Back, Cone

offers a defence of his early methodology which clearly still has some force for him. There he points out that the concern of the Black Church with the person of Jesus Christ, with the Bible as the Word of God, and with preaching as the means of communicating the Word of God today, is closely paralleled by Barth's emphasis on the three-fold form of the Word of God, the Revealed Word in Jesus Christ, the written Word in the Bible and the Word preached (Forrest, 1987:36-37; cf. also Cone, 1986:80-81).

Forrest further posits that "there is little evidence that Cone wished to give any revelational significance to the black experience per se" (1987:37). Unlike his critics, he did not consider the use of Barthian theology as alien to black experience, nor as conservative. This is why, taking into account the criticism from his brother Cecil and Wilmore among others, and having accepted the validity of their argument that "Black religion or the Black religious experience must become one of the important ingredients in the development of a Black Theology" (Wilmore \& Cone 1979:618), Cone eventually settled on:

a norm which would emerge as a harmony between the black condition and the Biblical revelation, so that there could be no talk of liberation without reference to Christ and no talk of Christ without reference to black liberation (Forrest, 1987:35-36; cf. also Cone, 1970:76; 78-79).

However, while Cone consistently sought to operate within such a hermeneutical circle in which situation and gospel are related dialectically, "the biblical Christ who is present in the black experience but not limited to it" (Wilmore \& Cone 1979:619) remained for him the ultimate norm of BT. In the face of the critique that he received from his brother Cecil, as well as Gayraud Wilmore, Cone insisted that Jesus Christ was the final norm in his perspective on Black theology not because he

"very little to do with the skin colour" (1997:151). Rather, it refers to the realities of oppression and dehumanization experienced by a wide range of people around the world. "The point is not whether Jesus is phenotypically black, but whether he is fully and irrevocably committed to the needs of the oppressed" (Cortez, 2016:199). 
studied theology at a white seminary, but rather "because, and only because, [Jesus Christ] was the final norm for the black church" (1986:97). Cone was also critical of his brother's "superficial" analysis of black religion (Wilmore \& Cone 1979:618) which seemed to lead him to "understand black religion in such spiritual terms that it was distanced from all politics" (1979:620). Not least, he objected to the pluralistic tendency represented by Wilmore and Cecil Cone, among others, by pointing out that "while they do not reject the possibility of Black theology, both fail to say what Black theology would look like if their suggestions about Black religion were taken seriously" (Cone 1993:434).

For similar reasons, Cone could hardly resonate with Charles Long's emphasis on the vitalness of Africa, particularly in the Afro-American religious consciousness (Hopkins 2005:85). While for Cone the departure point and the basic frame of reference was the experience of the black church in the U.S., Long situated his analysis of black religiosity in the broader context of Atlantic world understood as a space of "in-betweenness" between the continents of Africa, Europe, and the Americas, within a "history as terror" (Long 1999:19). In the same vein, Long insists that the task of thought relative to blackness is:

more than an accusation regarding the actions and behavior of the oppressive cultures; it goes to the heart of the issue. It is an accusation regarding the world view, thought structures, theory of knowledge, and so on, of the oppressors. The accusation is not simply of bad acts but, more importantly, of bad faith and bad knowledge (Long 1995:208).

This is why Eurocentric methodological tools, like those on which Cone's BT relied for the most part, prove insufficient in the hermeneutics of blackness and black religiosity in particular. To use Long's phrase, they fail to penetrate "the opacity of black religion" (Long 1995:107). The latter cannot be adequately interpreted without considering its specific substratum. One of the elements of this substratum, according to Long, is "the religious image and historical reality of Africa" (Long 1995:110). If Africa is indeed in the DNA of Black Americans, then Long's question is well justified: "How can African Americans worship God in the U.S. and not be aware of some religious and theological relatedness to Africa?" (Hopkins, 2005:85; cf. also Long, 1995:110). Cone's major objection against Long's critique had to do with Long's insistence on the fundamental distinction between theology and history of religions. Long equated the latter with an objective phenomenological comparison between existing religions, while reducing the former to dabbling in subjective faith claims, which in his view left theology open to the imperialistic manipulations by whites. Needless to say, to Cone, this depiction of theology as "inherently an 
unusable tool for black political and cultural liberation" (Hopkins, 2005:85) was unacceptable.

\section{Black theology à la James Cone: Christian or African?}

There is no doubt that Cone's attitude toward Africa has changed significantly over the years, as a result of his involvement in dialogue with African scholars and church activists (mainly through two ecumenical organisations: NCBC and AACC). A number of intercontinental consultations have contributed to this shift in Cone's outlook, notably in Dar es Salaam, Tanzania (1971), ${ }^{6}$ New York City (1973), ${ }^{7}$ Ghana (1974) ${ }^{8}$ where the two major contributions were offered by John Mbiti $(1974)^{9}$ and Desmond Tutu (1975) $)^{10}$ and finally; the Pan-African Conference of Third World Theologians [organised by Ecumenical Association of Third World Theologians (EATWOT)] at Legon in Accra, Ghana, in 1977, which brought together participants from Africa, Asia and Latin America with a small Black American participation including Cone, Wilmore, Jacquelyn Grant and others. ${ }^{11}$

While through those encounters Cone certainly recognized the deep-seated connections between North American and African experiences and struggles, he remained consistent in his emphasis on "faithfulness to biblical revelation" as a pillar on which BT's hermeneutics must rest. At the core of his "message" to African theologians was the insistence that the development and future of BT in Africa was contingent on its "creative interpretation of the Gospel for the African situation and in relation to the theologies of the poor throughout the world" (1979:181). Cone accorded a limited and relative significance to "African Theology's concern with indigenization and selfhood in the attempt to relate the biblical message to the African cultural and religious situation" (1979:181) by stressing that these should

6 This first Consultation, which took place from August 22 to 28, 1971, was attended by about 40 participants equally divided between Black Americans and Africans (Martey, 2018).

7 At this point, James Cone's understanding of theology had begun to influence and shape not just Black theology but also AfricanTheology (Martey, 2018).

8 This Third Consultation in Accra took place from December 29 to 31, 1974.

9 Some years later commenting on Mbiti's account of BT, Cone wrote: "I was especially disturbed by Mbiti's assertion that 'Black Theology... is full of sorrow, bitterness, anger and hatred.' I know of no black American theologian who would accept this description of Black theology" (1979:185, note 5; cf. also Martey, 2018).

10 This paper was presented at the 1974 meeting, but was first published in the Journal of Religious Thought 32(2) in 1975. The critical difference between African Theology and BT, as described by Tutu, had to do with their respective foci on Africanization and liberation. The significance of the Ghana Consultation consisted, among other things, in the fact that this very difference "could not be defined simply between Africans and Black Americans but also among Africans and among Black Americans" (Martey, 2018).

11 The papers presented at this conference were published In Appiah-Kubi, K. and Torres, S. (eds.). 1979. African Theology en Route. Maryknoll, New York: Orbis Books. 
never be reduced to cultural changes alone. ${ }^{12}$ Talking about indigenization, Cone also referred to Eliewaha Mshana's view according to which:

Africanization must involve liberation from centuries of poverty, humiliation, and exploitation. A truly African Theology cannot escape the requirement of helping the indigenous churches to become relevant to the spiritual, social and political ills of Africa (Cone, 1979:181-182; cf. Mshana [Wisconsin Lutheran Quarterly 71-72], 1974:13, cited in Cone \& Wilmore, 1993:398).

First, this confirms Cone's political emphasis (perhaps even bias) in addressing the issues of Africanization: an emphasis on political liberation at the expense of seeking cultural identity and integrity. Second, it also points to the one-sided tendency in his thinking whereby it is theology that should inform and shape the spirituality and political sensitivity of indigenous churches, but not vice versa. Convinced about "the universal dimension of the Gospel that transcends culture" (Cone, 1979:180), Cone does not seem to attribute much value to the potential of indigenous cultures / religions to inform and shape Christian theology as such. Although his insistence that "indigenization and liberation belong together" (1979:184) could suggest otherwise, one needs only to probe what Cone actually means by "indigenization" to realise that his view of indigenization/Africanization does not go beyond the traditional theological concept of inculturation. ${ }^{13}$

Without the indigenization of theology, liberation theology's claim to be derived from and accountable to oppressed people is a farce. Indigenization opens the door for people's creative participation in the interpretation of the Gospel for their life situation... From their earliest attempt to create an African Theology, African theologians have agreed that their theology should give careful attention to three sources: Bible, ATR, and the African Independent Churches (AIC). The appropriation of these sources structurally locates the theological task among the poor people of Africa (1979:184).

Thus, Cone equates indigenization/Africanization with Christian theology's "creative appropriation of the language and culture of the people... taking seriously popular religion and unestablished expressions of Christianity... the symbols and beliefs of

12 In this context, he underscored that the political could not be excluded from biblical hermeneutics: "There is a political ingredient in the Gospel that cannot be ignored if one is to remain faithful to biblical revelation" (Cone, 1979:179).

13 The minimalistic version of this concept entails considering African culture and ATR as, at best, preparatio evangelica. Those who advocate this position have been often highly critical of African culture / religiosity “as something to be converted from" (Maluleke, 2005:477-478). 
the people whom all liberation theologians claim to represent" (1979:183). His notion of creative appropriation of Africanness by Christian theology is essentially different from that of an egalitarian dialogue between (or even integration of) the two which underlies a number of contemporary interpretations of African Christianity in general and AIC in particular (cf., for example, Vellem, 2014:3; Maluleke, 2005:486). One important difference between these two concepts is that, while for Cone creative appropriation of Africanness basically serves the purpose of locating the theological task among the indigenous people (1979:184), the notion of the interaction of Christianity and Africanness as equal partners presumes that, not only does Christianity inform, shape and when needed correct the culture, but also vice versa (Urbaniak 2018a:22-28).

In Cone's defense, he does not attempt to impose his views on African theologians, affirming that "the future of African Theology belongs to Africans alone" (1979:177).${ }^{14} \mathrm{He}$ is also honest about the unavoidable impact of his North American location on his theological statements regarding Africa:

It is difficult for me to speak about the future of African Theology without relating it to social and political context of black people's struggle for freedom in the United States of America. The effect of this social reality upon my theological perspective could blind me to the uniqueness of the African situation (Cone 1979:176).

Cone should also be acknowledged for recognising the challenge that African Theology and African Christianity at large pose to "all Christians in the Third World (sic)" (1979:183) through their "rejection of prefabricated theology, liturgies and traditions... and focusing of the theological task on the selfhood of the church and the incarnation of Christianity in the life and thought of Africa" (1979:183).

It is telling, however, that Cone identifies the addressees of this challenge as "all Christians in the Third World (sic)" (1979:183), excluding from the equation, it seems, his own black church in the U.S. Indeed, another implication of the Conian shallow view of indigenization mentioned above is that Africanness has nothing to offer to Christianity as such. While ATR may have some significance to African Christians, as they find culturally relevant ways of expressing their Christian faith, yet they bear no meaning for the black church in the U.S. Indeed, black Christians in North America must be protected from any form of Africanism that could lead to their faith being replaced by ATR (1986:98). There seems to be quite a wide space between not acknowledging any potential meaning of ATR for Christianity in general

14 In the same vein, Cone asserts that "persons who have little or no knowledge of Africa or whose theological consciousness was shaped elsewhere should not expect to play a decisive role in the future development of the theology on the African continent" (1979:178). 
and the black church in the U.S. in particular on the one hand, and the somewhat unrealistic threat of ATR replacing Christianity on the other. To my knowledge, Cone has never deliberately engaged that space.

What is clear is that Cone's views on Africa and Africanness cannot be adequately understood in isolation from his ongoing concern with BT's Christian soul which, in his eyes, had to be protected from some black nationalists, scholars and activists who were "openly anti-theological and anti-Christian in their analysis of black religion" (Cone 1986:97). More significantly, according to Cone, the Christian soul of BT also needed to be protected from the pluralistic and broad definition of black religion which considered ATR and other non-Christian sources alongside the gospel as crucial elements of the substratum of black religiosity at large (1986:97). This supports my thesis that, Cone's engagements with African theologians notwithstanding, in his construing of the Black Theology of Liberation, the binary view of Christianity and Africanness has never been truly overcome.

\section{Western Christianity as Cone's chief locus of ennunciation}

In tune with some of his North American critiques cited above, I believe that Cone's Western location was the main reason behind the unresolved tension between Christianity and Africanness, a tension inherent in his theological outlook. More specifically, it was Western Christianity that not only informed many of his theological insights, but also provided a frame of reference for his critique of the West (and especially of Western imperialism as a source of oppression of black people).

As a student of Karl Barth, Cone was Christocentric in his black theological hermeneutics. He was also "much enamoured with Barth's theology of the word: proclaimed, written and revealed, the role that Barth assigned to the church as a bulwark against the authoritarian and repressive state, and his trenchant Christology" (Kalu 2006:582). A deeply Barthian influence can be seen also in Cone's firm belief that "God has been fully revealed in the man Jesus so that the norm for all existence is determined exclusively by him" (Cone 1970:51). Jawanza Eric Clark asks pointedly whether:

Cone's Christ was normative to black experience before the African spiritual holocaust. Is [Cone] referring strictly to post-Civil War black experience, the institutionalized black church experience, and is the Christ that is normative to that experience a fully indigenous creation or an alien intruder? (Clark 2012:12-13).

Cone's dependence on Eurocentric theology and his indebtedness in "an alien theological methodology" (Cone [Cecil 1974:77]), can be accounted for by his reliance on Western theological sources like Karl Barth, Paul Tillich, Dietrich Bon- 
hoeffer, John Macquarrie and the Niebuhr brothers (especially Reinhold whom Cone considered as the most influential theologian and ethicist of the 20th century in America). As Cone himself confessed in My Soul Looks Back:

I am embarrassed by the extent of my captivation by white concepts. And I realize that I am still partly enslaved by them. The struggle to overcome this enslavement has been a constant struggle in my intellectual development. That is why I will always be indebted to my black colleagues for assisting me in this endeavor (Cone, 2012:77).

On the other hand, one cannot dismiss the fact that Cone deliberately and programmatically distanced himself from the tradition of white theology. In the same book, he recalls the shift in his theological thinking, marked by his 1968 visit to Elmhurst College and writing the essay titled "Christianity and Black Power":

It seemed that both my Christian and my black identity were at stake. My first priority was my black identity, and I was not going to sacrifice it for the sake of the white interpretation of the gospel that I had learned at Garrett. If Christ was not to be found in black people's struggle for freedom... if he were in rich white churches and their seminaries, then I wanted no part of him... It became clear to me that my intellectual consciousness should be defined and controlled by black history and culture and not by standards set in white seminaries and universities... It was like experiencing the death of white theology and being born again into the theology of the black experience... (1986:44-45).

There is no doubt that this epistemic shift rooted in Cone's spiritual journey and his awakening to the call of unequivocal political commitment toward the liberation of black people resulted in the radical re-construction of the parameters for his BT to come. Apart from it being shaped by the contextual re-reading of Scripture and a new theological method, Cone's BT consistently drew from the spiritual wells of the slave religion and was grounded in the broader political and cultural currents within the civil rights movement of the 1950s and the subsequent rise of Black Power during the 1960s in the U.S. (Hopkins 1999:12). However, it seems fair to posit that once Cone found Christ "in black people's struggle for freedom" (2012:44), he has never felt inclined to seriously consider black people's experience at large (meaning also beyond Christian faith and outside the American context) as a theological locus. Thus, it was above all the North American black church's experience that informed Cone's anti-systemic and liberative theologising. Both the slave religion as well as the civil rights and Black Power movements constituted a reservoir of BT insofar as they found expressions in the black church's experience or, at least, 
proved compatible with and conducive to its struggle. Cone saw helping this black church "to be faithful to the task of preaching and living the liberating gospel of Jesus Christ in the world today" (Cone, 2012:77) as the chief task of BT.

There are two other factors which appear to support my view that Cone's location remained in essence Western, both with regard to his cultural and religious identity (that is, his blackness and his Christianity). I speak here of the central position that the notions of "critique" and "confession" occupied in Cone's frame of reference.

In his article on "Black Theology as Critical Theology" Edward Antonio (2018) seeks to demonstrate that Cone's appropriation of the notion of critique was both interruptive and disruptive of critique while utilizing critique. Antonio considers critique as a modern Kantian category whose genealogy includes Marx, Nietzsche, Freud, the thinkers associated with the Frankfurt School such as Adorno, Horkheimer, Habermas, post-structuralist philosophers like Foucault and practitioners of deconstruction like Derrida. His interpretation of BT as a particular form of "hermeneutic of suspicion" revolves around the claim that Cone's BT borrows heavily (also, albeit, dialectically) from another Sitz im Leben, namely the Western tradition of critique. Within the framework of Cone's BT, critique plays multiple roles: it is both a theological method and the medium within which its triple task (analysis, denunciation, and liberation / transformation) is carried out. This refers primarily to BT's activity of exposing the culpability of Whiteness as a death-dealing system, of uncovering its social basis. In this sense, Cone's critique of white theology presupposes a notion of Whiteness. This binary logic, Antonio argues, is at the core of Cone's theology. To sum up, while it entails a thorough, intellectuallyendowed hermeneutical suspicion of all Eurocentric thinking, at the same time BT à la James Cone is "from the beginning to the end a critical theology... a form of social criticism" and, as such, inscribes itself in the modern intellectual tradition of the West and is bound to Kantian declaration that ours is the age of criticism (Antonio 2018).

Reflecting on Cone's legacy in Africa and particularly his impact on the formation of the Kairos Document, Ogbu Kalu posits that confession served as a form of political praxis in Cone's theology. As one of the marks of the Christian church as such, confession has played a particularly significant role within the political realm in the Reformed tradition, which had a major impact on Cone, especially during his theological studies under Karl Barth. ${ }^{15}$ In the face of the unprecedented crisis

15 Unlike the Westminster Confession used by Reformed churches or the Augsburg Confession used by Lutheran churches, the African Methodist Episcopal Church of which Cone was a minister, bases its doctrinal standards on Wesley's Articles of Religion, an abridgment of the Thirty-Nine Articles of the Church of England that excised its Calvinist features (Melton, 2005:48). 
of the churches in Germany (1933/4), "when the Weimar Republic collapsed under the weight of military defeat, the decease of the democratic liberalism and the resurgence of National Socialism" (Kalu, 2006:577), Barth insisted that German Christians urgently needed the solidarity of Christians in foreign lands who should "join them in affirming a common confession in the midst of the intervention of the German Reich to repackage Christianity" (2006:578). As in the case of the Barmen Declaration of 1934, so in Cone's BT a few decades later situational confession, albeit much less formal than the Barthian one, appears as a re-definition of the relation between the Christian church and political reality, and thus as "a tool of protest" (2006:578). As Cornel West points out, the emergence of BT should be seen as a result of Cone's cry from the heart in the context of "the corpses of young black folk... [and] 329 uprisings in 257 cities between 1964-1969. And after 212 uprisings on the night that the bullets went through the precious body of Martin Luther King Jnr..." (West, 2007:13). As "the theological arm of Black Power seeking to relate the black struggle for freedom to the biblical claim regarding the justice of God," Cone's BT was "a brand of crisis theology" (Kalu, 2006:583), and confession became its basic medium. The role of confession as a form of political praxis was to bring to the surface the power of a hidden "'underground theology' that pulsates beneath the hard surface of the institutional structure" (2006:581; cf. also Wright, 2007:96-98). According to Cone, without this "common confession of faith [necessarily] related to a common historical commitment" (1979:179), the universality of Christian faith and of the church, remained nothing more than "the figment of our theological imagination" (1979:179).

Thus, one could argue that while the Western notion of critique provided $a$ theoretical framework for Cone's analysis, denunciation, and transformation of whiteness, the theological concept of confession equipped his theology with $a$ powerful political tool to re-define the relationship between church and social reality. What I wish to underscore is that both these notions are rooted in the intellectual and theological tradition of Western modernity.

It is worth noting that for Cone, the North American black church "symbolizes a people who were completely stripped of their African heritage as they were enslaved by 'Christian' white man” (Cone 1997:91). Jeremiah Wright, Jr. (2007:96) challenges this assumption. He argues instead that during the period of enslavement, African people were subject to a major and devastating assault on their African heritage "launched by the slave traders, the colonizers, and the slave holders [who sought to] 'season' the Africans in the Caribbean and 'break them in', so they would be more suitable as slaves" (Wright 2007:97). However, this assault notwithstanding, the fundamental aspects of their culture which were "stamped in the Africans' DNA" were not destroyed (Wright 2007:97). Indeed, Wright speaks of an "'under- 
ground theology' which was part and parcel of that [pre-Civil War] black church," a theology which advanced "changing the system of slavery in the here and now," even "destroying slaveholders if necessary" (Wright, 2007:97).

For instance, in Wright's view, Cone wrongly deemed most of the Spirituals otherworldly and compensatory in character (Cone 1997:93). On the contrary, in many slave narratives and the coded messages of the Spirituals, heaven was equated with “'goin' up North or going back to Africa" (Wright, 2007:97). Wright points out that a recurring motif of "resistance to oppression and refusal to bow down to the oppressor... runs from Queen Nzinga's resistance in Angola through [an African Episcopal Zion minister] Harriet Tubman's insistence on carrying a pistol!" (Wright, 2007:100101). Once again disagreeing with Cone, who believed that the post-Civil War black church lacked the creativity that characterised it before the war, Wright insists that the same strand of resistance ran "from Charles Tindley through Thomas Dorsey and the creation of... 'the sacred blues' - or gospel music - all the way up through the creation of the Spiritual church in North America" (Wright, 2007:101). All that suggests that the creative resistance of African people in the U.S., and particularly that of the black church, during the enslavement period and all the way through the era of the abolitionist movement and the civil rights and Black Power movements in the 20th century, prefigured in many regards the contemporary BT à la James Cone.

\section{Concluding Remarks}

It should be made clear that my intention in this article was not to criticise Cone's BT because of its Western location. Rather, I sought, implicitly, to understand in what ways it is as a potential model for doing theology in and for South Africa today. In the context of African experience in general and African Christianity in particular, and according to his African American critics, Cone's BT is "inconsistent with the full range of the black religious experience" (Clark, 2012:12). This is due to its "alien theological methodology" (Cone [Cecil, 1974:77]), and particularly because of the way in which it makes a certain notion of Christ - Christ who is an alien intruder, rather than a fully indigenous creation - normative to black experience (Clark, 2012:12-13).

This does not mean, by the way, that African American critics of Cone necessarily succeeded where he failed. Let me use Wilmore as an example. Although much more inclusive of non-Christian sources in black religion, ultimately even Wilmore's black radicalism remains inherently conditioned (and thus limited) by his Western locus of enunciation. Wilmore's interest in the "fluctuating resistance" of the ATR is mainly historical and ethnographic in nature, since it is contingent on his central focus, namely "black religion's progress in the New World" (1999:21). This is why, early on in his analysis of black religion, he finds it appropriate to 
"leave behind the crucible of West Africa where the spiritual gifts and sensibilities of African Americans were melted and molded" and concentrate instead on the "essence of that ancient spirituality" which found refuge in the religion of the slaves and which then reasserted itself "in the great African American churches of the twentieth century" (1999:21). ${ }^{16}$

A quick look at the views of another African from the West, may shed more light on Cone's attempts at problematizing "black identity in the context of African Theology" (1979:177). Similarly, to Cone-the-American, U.S. found himself "striving to be both European and black" (2003:1). While navigating between these identities and searching for "some specific forms of double consciousness" (2003:1), Gilroy was intentional about not allowing any particular identity to degenerate into a purely ethnic or national(istic) concern. He believed that living in Great Britain or in the U.S. bore out similar kinds of limitations, but also some openings (Gilroy, 2003:4). This is how he arrived at the notion of "Black Atlantic" which can be seen as his own attempt at "a reversal of colonialism and slavery" (Engdahl, 2017:1). Engdahl describes this notion as follows:

Settling for talking about Black Atlantic, Gilroy has several things in mind. There is the sea and its borders like the continents of Africa, the Americas and Europe. There is the continuous movement west and east, north and south. There are ships and there are people of various categories on these ships. Things here are never standing still. There is perpetual motion. Not to be forgotten, this fluid, ever moving reality, also has a long and very deep history... One can easily see that the very nature of an ocean would work against any definitive understanding of social reality in terms of, for example, nationalisms or ethnicities (2017:1)

Indeed, Gilroy praises thinkers "who were prepared to renounce the easy claims of African-American exceptionalism in favour of a global, coalitional politics in which antiimperialism and anti-racism might be seen to interact if not to fuse" (Gilroy, 2003:4).

Up to this point, Gilroy's notion of Black Atlantic appears to resonate with Cone's concept of the Black World. To Gilroy, as to Cone, the relationship between modernity on the one hand and colonialism/slavery on the other hand, is an "unfinished business" (Engdahl, 2017:2). The only significant difference is that the former fo-

16 This explains why Wilmore sought to demonstrate the correspondence between more or less characteristic aspects of many ATR and some of the major facets of Judeo-Christian tradition. "It is not too rash to speculate," he claims, "that the relative ease with which [the later introductions of Christianity in African contexts] were able to mix with the belief systems of ATR had something to do with the alacrity with which many of the slaves who were taken to the New World were able to convert and syncretize their new faith in Jesus with the religious traditions they brought with them across the Atlantic" (Wilmore, 2004:118). 
cuses on overcoming nationalisms and ethnicities, while the latter on solidarity with the world's poor (Cone, 1979:179). But in terms of the political horizon against which Gilroy's Black Atlantic and Cone's Black World are set, both notions revolve around the "liberation of the Black World [the Black Atlantic] from European and American domination" (1979:179).

However, Gilroy's reflection on the Black Atlantic seems to open itself to another dimension which is absent in Cone. As Engdahl puts it:

Even though Gilroy shuns essentialist ways of understanding peoples and cultures, it goes without saying that in the West at least the very notion of a Black Atlantic creates a barrier. But this is exactly the point. Without such a notion, the African diaspora emerging into America and now Europe is made invisible (2017:2).

The only way in which Cone's Black World may be seen as "creating a barrier" within and for the West, is in terms of its united claim to political and economic liberation from Western imperialism. To Gilroy, the meaning of this "barrier" provided by the Black Atlantic goes deeper. The overturning of modern imperialism, with its inherent racism and white supremacy, requires in his view rethinking "modernity via the history of the Black Atlantic and the African diaspora into the western hemisphere" (Gilroy, 2003:17).

It may be worth noting that, in comparison with their black counterparts from the West like Cone or Gilroy, African decolonial thinkers tend to denounce the death-dealing systems of power and exclusion inherent in the modernist ethos in a much more radical and uncompromising manner. For instance, Ngugi wa Thiong'o considers "the founding moment of capitalist modernity and Western bourgeois ascendancy in the world" as "the beginning of the wanton destruction of many city civilizations along the coast of Africa, Eastern Africa in particular" (2009:52). In the same vein, Vellem asserts that the beginning of the destruction of African civilisations is inextricably tied to the ascendancy of capitalist modernity and the expansion of Western Christianity (2014:1). He extends this interpretation of modernity by claiming that death dealing imperial mechanisms in the $21 \mathrm{st}$ century, which are "a convergence of military power, politics, economics and culture" (2014:4), are underpinned by the same logic that was a driving factor behind colonialism and slavery.

The brutal force of domination that was used to dismantle the black African dispensation shifted to hegemony which masquerades the initial bloodied and genocidal era of disruption to a more sophisticated dispensation in which a combination of all these strategies - mainly to maintain economic hegemony and, in fact, the control of the whole of life by empire - must be maintained (2014:3-4). 
A distinction between a postcolonial critique and a decolonial project on which I elaborate somewhere else (Urbaniak, 2018b; cf. also Sithole, 2014:34-37) sheds more light on the differences inherent in Euro-American and African approaches.

In this article I argued that the limitations inherent in Cone's theological perspective should be seen as correlates of his chiefly Western location and locus of enunciation. If Wright's interpretation is correct, it would mean that these limitations render Cone's BT problematic not only from a broadly African (indigenous African people's) point of view, but that a methodological corrective may be also required with regard to Cone's view of the black church, the primary locus and recipient of his theology, in the U.S.

Whether the black church in North America should (have) more deliberately create(d) spaces for its members (and for African Americans in general) where they could experience their Africanness (Africanity) being (re-)affirmed and where they could celebrate their African roots / heritage, and what role BT could (have) play(ed) in such a process, is a question for African Americans to answer.

Personally, I am interested in the forms in which such affirmation and celebration are already taking place and in which they could be still pursued..$^{17}$ Further, I am curious about the potential role and significance of such spaces as sites of creative resistance in a broader societal context marked by structural racism and division (this would certainly apply to the current-day U.S. with its society seemingly more politically polarised than ever, at least since the Civil War, and with vile, unadulterated racism made the norm of the day under Trump's regime). I hope that black ministers and theologians from across the Black Atlantic, among others, share those interests and will continue to test and reflect on the relevance of such spaces in the North American contexts. ${ }^{18}$

As for me, the ultimate reason why these and similar questions matter to me and the reason why I chose to probe Cone's attitude towards Africanness in general and African religiosity in particular - is that, I believe, analogical questions present themselves to us who live in and try to make sense of South African reality today, including whites like myself. I therefore continue this reflection in another article

17 Jeremiah Wright's Trinity United Church of Christ in Chicago seems to be a good case in point. Wright lists a number of ways in which this community seeks to embody an African-centred perspective, starting from the premise that Christianity was not born in Europe, but in Africa (2007:101). The Center for African Biblical Studies, seventy different ministries proceeding from an African-centred world view, many of which use Swahili names, Africa as a starting point for music, worship style, pedagogy and not least for the underlying theology, to list a few (2007:101).

18 Among a few sources that have drawn my attention so far, let me mention: Mitchem (2018:85-104; 167-190); Robertson (2018); Erskine (2014); Stuckey (2014); Clark (2012); Etuk (2011); Hackett (2008); Adamo (2001:41-77); Walker (2001); Stewart (1999). 
(cf. Urbaniak, 2018b), where my focus is on James Cone vis-à-vis African religiosity considered from a decolonial perspective.

\section{References}

Adamo, D.T. 2001. African American Heritage. Eugene, OR: Wipf and Stock Publishers. Antonio, E.P. 2018. "Black Theology as Critical Theology." Journal of Theology for Southern Africa (Special Edition on James H. Cone ed. by V.S. Vellem \& T.S. Maluleke) [in publication].

Clark, J.E. 2012. Indigenous Black Theology: Towards an African-Centered Theology of the American-American Religious Experience. New York: Palgrave Macmillan.

Cone, C.W. 1974. The Identity Crisis in Black Theology by Cecil Wayne Cone. Atlanta, GA: Emory University.

Cone, J.H. 1970. A Black Theology of Liberation. Philadelphia: Lippincott.

- - - 1979. "A Black American Perspective on the Future of African Theology." In K. AppiahKubi and S. Torres (eds.). African Theology en Route. Maryknoll, New York: Orbis Books, pp. 176-186.

- - 1986. My Soul Looks Back. Maryknoll, NY: Orbis Books.

- - 1993. "Epilogue: An Interpretation of the Debate among Black Theologians." In J.H. Cone \& G. Wilmore (eds.). Black Theology: A Documentary History, Volume One. New York: Orbis Books, pp. 425-440.

- - - 1997. Black Theology and Black Power. Maryknoll, N.Y.: Orbis Books.

Cone, J.H. and Wilmore, G. 1979. Black Theology: A Documentary History, Volume One. New York: Orbis Books.

Cortez, M. 2016. "The Black Messiah: Race, Liberation and the Actualization of Humanity in James Cone's Christological Anthropology." In Christological Anthropology in Historical Perspective: Ancient and Contemporary Approaches to Theological Anthropology. Grand Rapids: Zondervan, pp. 190-217.

Du Bois, W.E.B. 2018. The Souls of Black Folk. Gorham, ME: Myers Education Press.

Engdahl, H. 2017. "The Black Atlantic as Reversal: A Reappraisal of African and Black Theology." HTS Teologiese Studies/ Theological Studies 73(3), a4618. https://doi. org/10.4102/hts.v73i3.4618.

Erskine, L.N. 2014. Plantation Church: How African American Religion was Born in Caribbean Slavery. New York: Oxford University Press.

Etuk, E.S. 2011. From David Walker to Barack Obama: Ethiopianists as Keepers of the African Dream. Bloomington, IN: iUniverse.

Forrest, M.R. 1987. "Christology from Below: An Examination of the Black Christology of Takatso Mofokeng in the Context of the Development of Black Theology in South Africa and in Critical Relation to the Christological Ethic of Dietrich Bonhoeffer." A Master Thesis in Religious Studies. Cape Town: University of Cape Town, available at https:// goo.gl/k1dfrB [accessed 15 September 2018].

Gilroy, P., 2003 [1993], The Black Atlantic. Modernity and Double Consciousness. Cambridge, MA: Harvard University Press. 
Hackett, D.G. 2008. Religion and American Culture: A reader. New York: Routledge.

Kalu, O.U. 2006. "James Cone's Legacy in Africa: Confession as Political Praxis in the Kairos" Verbum et Ecclesia 27(2):576-595.

Küster, V. 2001. "The Black Messiah - Christology in the Context of Racism: James H. Cone (USA) and Allan A. Boesak (South Africa)." In The Many Faces ofJesus Christ: Intercultural Christology. Maryknoll, N.Y.: Orbis Books, pp. 137-151.

Long, C.H. 1995. Significations: Signs, Symbols, and Images in the Interpretation of Religion. Aurora: Davies Group.

Long, C.H. 1999. "Passage and Prayer: The Origin of Religion in the Atlantic World." In The Courage to Hope: From Black Suffering to Human Redemption, ed. Quinton Hosford Dixie and Cornel West. Boston, MA: Beacon Press, pp. 11-21.

Maluleke, T.S. 2005a. "Half a Century of African Christian Theologies: Elements of the Emerging Agenda for the Twenty-First Century." In O.U Kalu. African Christianity: An African Story. Pretoria: Dept. of Church History, University of Pretoria, pp. 469-493.

Martey, E. 2018. "In Memory of James Cone: A Dogmatic Gift to the Black and African Church and Theological Communities." Journal of Theology for Southern Africa (Special Edition on James H. Cone ed. by V.S. Vellem \& T.S. Maluleke) [in publication]. Mbiti, J. 1987. “An African Views American Black Theology.” Worldview 17(8):41-44.

Melton, J.G. 2005. Encyclopaedia of Protestantism. London: Eurospan.

Mitchem, S.Y. 2018. Race, Religion, and Politics: Toward Human Rights in the United States. Lanham, MD: Rowman and Littlefield.

Ngugi wa Thiong'0. 2009. "Recovering our Memory: South Africa in Black Imagination." In Steve Biko Foundation, The Steve Biko Memorial Lectures 2000-2008. Johannesburg: Pan Macmillan, pp. 51-72.

Robertson, C. 2018. "A Quiet Exodus: Why Black Worshipers Are Leaving White Evangelical Churches." The New York Times 9th March, available at https://goo.gl/pV4CGy [accessed 15 October 2018].

Schleiermacher, F. 1928. The Christian Faith. Edinburgh: T. \& T. Clark.

Stewart, C.F. 1999. Black Spirituality and Black Consciousness: Soul Force, Culture, and Freedom in the African-American Experience. Trenton, NJ: Africa World Press.

Stuckey, S. 2014. Slave Culture: Nationalist Theory and the Foundations of Black America. New York: Oxford University Press.

Tutu, D. 1975. "Black Theology/African Theology - Soulmates or Antagonists?" Journal of Religious Thought 32(2):25-33.

Urbaniak, J. 2018a. "Between the Christ of Deep Incarnation and the African Jesus of Tinyiko Maluleke: An Improvised Dialogue.” Modern Theology 34:1-29, https://goo.gl/ nRGz2E.

- - - 2018b. "James Cone vis-à-vis African Religiosity: A Decolonial Perspective" [under review].

Vellem, V.S. 2014. "Spirituality of Liberation: A Conversation with African Religiosity." HTS Teologiese Studies/Theological Studies 70(1), Art. \#2752, 7 pages. https://goo.gl/ LU9UbP.

- - 2018. "The Memory of James Hal Cone: The Father of Black Theology of Liberation, Charles Briggs Distinguished Professor of Systematic Theology at Union.” 4th May. Le- 
kgotla of the Faculty of Theology and Religion of The University of Pretoria, available at https://goo.gl/Yy4uQx [accessed 10 September 2018].

Walker, S.S. (ed.). 2001. African roots, American cultures: Africa in the creation of the Americas. Lanham: Rowman \& Littlefield, 2001.

West, C. 2007. "Black Theology and Human Identity." In D Hopkins (ed.). Black Faith and Public Talk: Critical Essays on James H. Cone's Black Theology and Black Power. Waco: Baylor University Press, pp. 11-19.

Wilmore, G.S. 2004. Pragmatic Spirituality: The Christian Faith through an Africentric Lens. New York: New York University.

Wilmore, G.S. and Cone, H.J. (1979). Black Theology: A Documentary History, 19661979. Maryknoll, N.Y.: Orbis.

Wright, J., Jr. 2007. "An Underground Theology.” In D. Hopkins (ed.). Black Faith and Public Talk: Critical Essays on James H. Cone's Black Theology and Black Power. Waco: Baylor University Press, pp. 96-102. 